\title{
A MAGYARORSZÁGI INNOVÁCIÓ HELYZETE ALULNÉZETBŐL
}

A dolgozat 23 interjú tapasztalatait összegzi az innováció helyzetével kapcsolatban, melyeket fóként hazai tulajdonú kis- és középvállalatokkal készítettek a szerzók 2008 októbere és 2009 februárja között. A megkérdezett cégek többségében a kormányzat részéról húzóágazatként megnevezett jármúiparhoz és információtechnológiai iparághoz tartoznak. A vállalatok túlnyomó többsége az innováció egyik fontos akadályozó tényezôjének tartja a finanszírozási források szúkösségét: nincs pénzük $\mathrm{K}+\mathrm{F}-\mathrm{re}$, innovációra, $\mathrm{s}$ korlátozottak a lehetőségeik külsố források bevonására is. A jobb gazdasági helyzetben lévô cégek inkább a megfelelố kvalitású szakemberek hiányában látják az innováció fó gátját. Bár az egyetemek és a vállalatok innovációs együttmúködésében az eltéró szervezeti kultúrák okoznak némi súrlódást, a fejlesztési tevékenységet folytató cégek összességében hasznosnak tartják az egyetemekkel való együttmúködést.

Kulcsszavak: innováció, versenyképesség, kis- és középvállalatok

A Budapesti Corvinus Egyetem Versenyképességi Kutatóközpont „Versenyben a világgal 2007-2009” kutatási programjának keretében 2008 októbere és 2009 februárja között lehetőségünk nyílt személyes interjúkon alapuló kutatás lefolytatására a hazai kis- és középvállalatok innovációs tevékenységével kapcsolatban. Az OECD hazánk innovációs állapotairól készült legutóbbi felmérése szerint Magyarország egy duális gazdaság képét mutatja: egyik oldalon vannak a nagy, tipikusan külföldi tulajdonú vállalatok, melyek integrálódtak a nemzetközi termelési, elosztási és részben $\mathrm{K}+\mathrm{F}$ és innovációs hálózatokba, másik oldalon a magyar tulajdonú kkv-k, melyek innovációs képességei alacsony színvonalúak, s fóként a magyar piacra termelnek. Halvány pozitív jelként említi a tanulmány, hogy néhány területen megjelentek magasabb vevői igényekhez alkalmazkodni tudó beszállítók (például az autóipari klaszterben), és nagyon kis számban ugyan, de kutatás-fejlesztésre alapozó kis cégek is (OECD, 2008).

Kutatásunk célja az volt, hogy a hazai innováció sokak által és sokszor diagnosztizált problémáival szembesítsük a megkérdezett vállalatokat: hogyan, milyen mértékben jelentkeznek ezek náluk, látnak-e a maguk számára kitörési lehetôségeket, s ezek megvalósítását hogyan tudná támogatni az állam. A következő kérdésekre kerestünk többek között választ:
- Az Európai Unió által rendszeresen elvégzett Magyarországra vonatkozó Közösségi Innovációs Felmérések (Eustat, 2006) és korábbi saját kérdőíves „Versenyben a világgal” felmérésünk (Kiss, 2005) szerint is az innováció legfő́bb gátját a finanszírozási források hiánya jelenti. Valóban így van-e ez, amikor például ma már nagyon sok pályázati lehetôség áll a vállalatok rendelkezésére?

- Miért nincs nagyobb igény a kkv-k részérôl az egyetemek, kutatóintézetek szolgáltatásaira, illetve megfeleló-e ezeknek az intézményeknek a kínálata számukra?

- A megfelelố szakemberek hiányát is az innováció kiemelkedő akadályai között szokták említeni. Kérdésünk ezzel kapcsolatban az, hogy mennyiben vezethetô ez vissza oktatási rendszerünkre, illetve arra, hogy a legjobb szakemberek külföldre mennek dolgozni?

\section{A minta fóbb jellemzói}

A megkérdezett vállalatok többségében a húzóágazatnak tartott jármúiparhoz és információtechnológiai iparághoz tartoznak. Legtöbbjük esetében az elsó számú vezetôvel beszéltünk, illetve néhány esetben az általa megnevezett kompetens vezetótársával. Az interjúk közül hármat Unger Viktória ötödéves egyetemi 
A vállalatok fóbb jellemzôi 2008

\begin{tabular}{|c|c|c|c|c|c|c|}
\hline Vállalatok & Telephely & $\begin{array}{c}\text { Létszám } \\
\text { (fô) }\end{array}$ & Tulajdon & $\begin{array}{l}\text { Árbevétel } \\
\text { (millió Ft) }\end{array}$ & $\begin{array}{c}\text { Export } \\
(\%)\end{array}$ & $\mathbf{K}+\mathbf{F}+\mathbf{I}^{*}$ \\
\hline G1 & Tiszántúl & 440 & osztrák & n. a. & magas & A \\
\hline G2 & Dunántúl & 3 & magyar & n. a. & 0 & B \\
\hline G3 & Dunántúl & 225 & német $(90 \%)$ & $2700(2007)$ & 99 & B \\
\hline G4 & Budapest & 121 & magyar & 1100 & 65 & B \\
\hline G5 & Dunántúl & 106 & magyar & 1200 & 60 & $\mathrm{C}$ \\
\hline G6 & Tiszántúl & 41 & magyar & 850 (2007) & 40 & A \\
\hline G7 & Dunántúl & 30 & magyar & $150(2007)$ & 80 & A \\
\hline G8 & Dunántúl & 17 & magyar & 337 (2007) & 2 & $\mathrm{C}$ \\
\hline G9 & Budapest & 160 & magyar & $3000(2005)$ & magas & $\mathrm{B}$ \\
\hline G10 & Dunántúl & 35 & magyar & n. a. & 2 & $\mathrm{~B}$ \\
\hline G11 & Tiszántúl & 74 & magyar & $564(2005)$ & 80 & $\mathrm{~B}$ \\
\hline G12 & Budapest & 140 & magyar & 1400 & 30 & $\mathrm{~B}$ \\
\hline G13 & Dunántúl & 54 & magyar & 700 & 90 & $\mathrm{~B}$ \\
\hline G14 & Dunántúl & 1415 & vegyes & 36700 & 88 & B \\
\hline I1 & Budapest & 30 & magyar & 250 & magas & $\mathrm{C}$ \\
\hline 12 & Budapest & 40 & magyar & 400 & 20 & $\mathrm{C}$ \\
\hline I3 & Budapest & $40-50$ & magyar & 900 & 0 & $\mathrm{C}$ \\
\hline I4 & Budapest & 3 & magyar & 23 & 0 & B \\
\hline I5 & Budapest & 13 & magyar & n. a. & $95 \%$ & $\mathrm{C}$ \\
\hline I6 & Budapest & 116 & külföldi & 2800 & kevés & B \\
\hline I7 & Budapest & 14 & angol & n. a. & 95 & $\mathrm{C}$ \\
\hline I8 & Budapest & 15 & magyar & 500 & 0 & $\mathrm{C}$ \\
\hline 19 & Budapest & 15 & magyar & n. a. & 0 & B \\
\hline
\end{tabular}

G: Gép- és jármúipari vállalatok

I: Információtechnológiai vállalatok

${ }^{*} \mathrm{~A}=$ nincs innovációs tevékenység

$\mathrm{B}=$ termék és/vagy technológiafejlesztés

$\mathrm{C}=$ formális $\mathrm{K}+\mathrm{F}$ tevékenység

hallgató készített, a többit e cikk szerzője. Elsôsorban a Pannon Autóipari Klaszter (PANAC) és az IVSZ (Informatikai Vállalkozások Szövetsége) honlapján található lista alapján történt a megkeresés, a gépipari cégek esetében pedig más internetes céglistákat használtunk. A mintánkat alkotó 23 vállalat közül 9 tartozik az informatikai iparághoz, a másik csoport vállalatai közül 10 tagja az autóipari beszállítókat tömörítő PANAC-nak (Pannon Autóipari Klaszter) (1 mérnöki tanácsadás, 3 múanyagipar, 7 fémmegmunkálás, gépgyártás), 4 pedig a gépgyártás területén múködik.

Az 1. táblázatban foglaltuk össze a vállalatok legfóbb jellemzőit. Létszám szerint 2 mikrovállalkozás, 11 kisvállalkozás, 8 közepes és 2 nagyvállalat. Öt cég kivételével hazai magántulajdonban vannak. A jármú- iparhoz és gépgyártáshoz kapcsolódó cégek közül 3 budapesti, 8 dunántúli és 3 a keleti országrészben tevékenykedik. Az informatikai vállalkozások mindegyike budapesti. Formális $\mathrm{K}+\mathrm{F}$ tevékenységet többségében az informatikai cégek végeznek, jóval kevesebben a másik vállalati körben, ahol leginkább a gyártásfejlesztés a jellemző, illetve kisebb termékmódosítások, áttervezések. Három cég lényegében semmilyen fejlesztési tevékenységet nem végez.

\section{Az innováció helyzete a jármú- és gépipari vállalatokkal készült interjúk alapján}

\section{A beszállítói kapcsolatok jellemzói}

Az autóalkatrész-beszállítás piacán leginkább árverseny folyik, a kiváló minőség alapkövetelmény. Egyre gyakoribb az on-line árverés, amelyen Kínától Argentínáig minden potenciális beszállító részt vehet. Egyik interjúalanyunk szerint a kínaiak a legolcsóbbak, velük 
„revolverezik” a kelet-közép-európaiakat, velünk pedig saját országuk beszállítóit a nyugat-európai autógyárak. Persze a végsố döntésnél a földrajzi közelség is sokat nyom a latba.

A hazai autóipari alkatrész-beszállítók esetében a gyártási képesség a döntő, a legelsố feladatuk az újonnan rendelt alkatrészekhez a szerszámok és a szerszámgépek elkészítése. Az autógyárak a speciális eszközöket és ezek kifejlesztését vagy utólag kifizetik, vagy az árban ismerik el.

Többen említették, hogy néha sor kerülhet a megrendelt termék bizonyos áttervezésére is gyárthatósági szempontok miatt. A mintánkba bekerült haszongépjármú-részegységeket gyártó vállalat ezeken túl maga is fejleszt komplett futómúveket. Számukra az innovációs képesség megléte elengedhetetlen feltétele a piacon maradásnak, mivel megrendelóik elvárják tólük az újabb és újabb fejlesztéseket. Az is előfordul, hogy a megrendelő csak a fóbb paramétereket adja meg, s ez alapján kell kifejleszteniük az adott részegységet. A vevő-beszállító kapcsolatoknak ez a formája, ami a beszállító oldaláról nemcsak gyártást, de fejlesztést is tartalmaz, sajnos ritka a hazai cégek körében, versenyképességi szempontból pedig csak ez hozhat előrelépést. Az is igaz persze, hogy ez sokkal kockázatosabb, hisz ha hibás lesz az alkatrész, a károkat bizonyos százalékban a beszállítók fizetik.

Különösen a 2008 ôszén kezdődő, az autóipart nagyon érzékenyen érintő világválság hívta fel a figyelmet arra, hogy a bérmunkázás igencsak sebezhetóvé teszi a cégeket. Az egyik interjúalanyunk szerint ellenben a magyar vállalatok többségének nagyon megfelelő az, hogy a megadott dokumentációk alapján legyártsák a termékeket, s ne kelljen önállóan fejleszteni. Kivételek persze vannak, az egyik vállalat például nagyon tudatosan szakított az addigi beszállítói szereppel. Korábban kartámaszok gyártásával foglalkoztak, majd a gyártással felhagyva új modelleket fejlesztettek ki együttmúködve egy design és egy elektronikai céggel, s egy saját márkát hoztak létre. Ma csak fejlesztéssel foglalkoznak, termékeikkel ôk keresik meg a nagy autógyárakat, s megteremtették saját beszállítói hálózatukat. Az előrelépés szép példája az is, ahogyan egy másik cég kiterjesztette tevékenységét a légi ipar felé. Ez csak jelentôs beruházások árán volt megvalósítható, ami magában foglalta többek között új üzemcsarnok megépítését, hôkezelésre alkalmas gépek beszerzését, valamint a termékeket ellenőrző világszínvonalú anyagvizsgáló laboratórium felszerelését.

Különösen a fémalkatrész-gyártók (nem csak a jármúipariak) említették, hogy a gyors múszaki fejlődés következtében egyre nônek az elvárások, például a méretpontosságot terén. Fớként a kis- és középes vállalatok nem képesek a technológiai lépéstartásra, ami miatt alvállalkozóként versenyhelyzetük egyre romlik. Az utóbbi néhány évben az árbevétel tartása volt a cél, most el kell, hogy fogadják a csökkenését is. Több cégnél azt hangsúlyozták, hogy bár bizonyos területeken szükséges a legmodernebb berendezések beszerzése a megfelelő minőség biztosításához, más esetekben, mint például a sajtolás, a régi gépek is megteszik, ezek is tudják hozni a megfelelô minőséget. Azoknál a cégeknél, ahol a kis- vagy középsorozatos gyártás a jellemzô, termelékenyebb gépekre sincs feltétlenül szükség.

\section{Innovációs együttmúködések, vélemények az. oktatás helyzetéról}

Mintánkban hét vállalatnak vannak egyetemi kapcsolatai, ebbő́l három esetben az együttmúködés tartalma az, hogy teszteket, méréseket és anyagvizsgálatokat rendelnek meg az egyetemektôl. Az együttmúködés szorosabb formája, amikor közös fejlesztőmunka is folyik, illetve sokkal inkább testhezálló az egyetemek számára a fent említett rutinmunkáknál, ha kutatás-fejlesztést igénylő megbízásokat kapnak. Több jármúipari vállalatnál elmondták, hogy az adott területen a legjobb felszereltsége a Széchenyi István Egyetemnek van az országban. Azt is többen említették, hogy egyetemekkel közösen pályázva nagyobb az esélye a sikeres pénzszerzésnek a kutatásokra. Ezt bizonyítja a Jármúipari Regionális Egyetemi Tudásközpont (JRET), amely 2005-ben jött létre jelentôs állami támogatással, s 2008-tól meghosszabbították újabb három és fél évre. A második program költségvetése 1,25 milliárd forint, fele-fele arányban finanszírozza az állam és a Széchenyi István Egyetem mellett részt vevő négy vállalat, melyek közül három került be az általunk megkérdezett vállalati körbe.

Az oktatást úgy látják a vállalatok, hogy nemcsak az egyetemi, de a szakmunkás- és szakközépiskolai képzés is nagyon elszakadt a gyakorlattól, nem veszi figyelembe a vállalatok igényeit. A vállalatoknak azonnal hasznosítható tudásra lenne szükségük, ezzel szemben sokszor nekik kell kiképezniük a belépó szakmunkásokat, amire igazán nincsenek kapacitásaik.

\section{A pályázati lehetôségek megítélése}

Állami, leginkább technológiakorszerúsítési pályázatokon egy kivétellel mindegyik megkérdezett vállalat részt vett. A pályázatok lebonyolításával kapcsolatban nagyon sok kritika fogalmazódott meg, csak egy-két vállalat volt majdnem maradéktalanul elégedett. Egy autóipari beszállító azonban annyira elégedetlen az állami pályázatok túl hosszadalmas és bürokratikus voltával, hogy inkább nem él ezzel a pénzszerzési lehe- 
tôséggel. Megelégelték, hogy nagyon késő́n fizetnek, sốt „trükköznek” is, például a kifizetés esedékes napja elôtt találnak formai hibákat, amelyek kijavítása további hetekkel kitolja a kifizetést. Sokan megfogalmazták, hogy a pályázatoknál nem a tartalmi, hanem a formai dolgok a döntőek, jól kell adminisztrálnia magát a jelentkezőnek. Ezért a cégek közül három is pályázatíró céggel szerződött, amelyek bár elég drágán dolgoznak, de ốk ismerik azokat a sokszor nüansznyi dolgokat, ami a sikerhez kellenek.

Az eljárások kritikája mellett megfogalmazódtak olyan vélemények is, hogy például a finanszírozási gondok enyhítésére nagyobb arányban lenne szükség vissza nem térítendố támogatásra. Sokallják, hogy a gépbeszerzési pályázatokon $70 \%$ az önrész, s nehéz megfelelni a pályázati feltételek egynémelyikének, mint például a megtérülési elvárások vagy a munkaerô létszámnövelése.

A valószínúleg jogos kritikák ellenére összességében a vállalatok megtanultak együtt élni a pályázatok jellemzőivel, például banki hitelekkel orvosolják azt, hogy túlnyomó többségében utófinanszírozásról van szó. Az is az igazsághoz tartozik a pályázatokkal kapcsolatban, hogy a kevésbé tôkeerốs cégek, különösen a válság kezdete óta, a pályázati pénzeket is egyre inkább a túlélés eszközének tekintik.

\section{Az innováció helyzete az információtechnológiai vállalatokkal készült interjúk alapján}

\section{Piac, verseny}

A cégek többségénél azt tapasztaltuk, hogy az alacsony létszámból adódóan általában nem különül el a fejlesztési, tanácsadási és támogató (support) tevékenység, sốt a marketing sem - mindenki feladata az új ügyfelek felkutatása és a régiekkel való kapcsolattartás. Egy-egy kereskedőt, marketingest a megkérdezett vállalatok közül kettő foglalkoztat. Az új eladásokban a személyes kapcsolatoknak van nagy jelentősége, annak például, hogy meglévő ügyfeleik ajánlják ốket. Az egyik céget például azok a partnereik képviselik külföldön, akiknél már futnak szoftvereik. Ốk adják el a termékeket, s a cég csak a support tevékenység kapcsán találkozik velük a későbbiekben. Több cég is részt vesz nemzetközi vásárokon, ahol az érdeklődốknek bemutathatják termékeiket, s személyes ismeretségek alakulhatnak ki.

A megkérdezett vállalatok a versenyt nagyon élesnek tartják, mindenki igyekszik megtalálni azokat a piaci réseket, ahol jó pozíciókat építhet ki. Többen említették a multinacionális vállalatok kiszorító hatását, mivel nálunk is a már otthon bevált szoftvercégekkel fejlesztetnek. A magyarok a bankokról, biztosítókról, közszolgáltatókról lemaradnak, nekik az önkormányzati szféra és az egészségügy jut, amely legtöbbször fizetésképtelen. Az egyik megkérdezett cég azért zsugorodott az utóbbi években 25-30-ról három foóre, mert nem bírta a versenyt a kínai konkurenciával, amely a hazai azonosítási piacon komplett rendszereket kínált, amelyre a kis magyar cég nem volt képes. Az is általános tapasztalat, hogy a környezô országokban sem könnyú a piacszerzés, mert a magyarok helyett inkább a multikat választják a tendereken.

\section{Innovációs együttmúködések}

Mind a kilenc informatikai vállalat végez fejlesztéseket, közülük hat folytat formális $\mathrm{K}+\mathrm{F}$ tevékenységet. Az IVSZ becslése szerint egyébként száz alatti az igazán innovatív IT-cégek száma Magyarországon (Click, 2006). Három vállalat a $\mathrm{K}+\mathrm{F}$ tevékenységnek köszönhetően egy-egy szakterületen magas szintú kompetenciákat hozott létre: tesztelési módszerek, módszertanok, adatbányászati algoritmusok Bayes-hálók felhasználásával, termikus tranzienstesztelés.

A nemzetközi projektekben való részvételnek köszönhetóen a cégek új technológiákat, módszereket ismerhetnek meg, s olyan értékesithetó tudásra tehetnek szert, mely más piacokon is eladható, s nem mellesleg a kapcsolati tókéjük is növekszik. A mi vizsgálatunkban három vállalat vesz részt nemzetközi innovációs együttmúködésekben, amelyekbe való bekerülésükben nagy szerepe volt a kapcsolati tókének. Az egyik cég esetében a vezetố korábbi tudományos munkásságából származó ismeretségei bizonyultak e szempontból is hasznosnak, a másikat egy francia nagyvállalat hatására választották ki, amellyel korábban együttmúködtek, a harmadiknak pedig kanadai tulajdonosa volt még pár éve, ez is hozzásegítette, hogy nemzetközi nagyvállalatok projektjeiben vegyen részt. A kapcsolati tóke azonban csak az indulásnál segíthet, a jó munka s valamely szakterületen kivívott tekintély alapozhatja meg, hogy a késôbbiekben is ôket hívják meg.

Az egyetemekkel kapcsolatban néhány kritika is megfogalmazódott. Elhangzott például, hogy a kutatók számára elsôdleges a tudományos elốmenetel, a cikkírás, kevésbé érzékenyek ellenben a projekthatáridốkre. Állítólag az is megesett, hogy a határidốcsúszást az egyik cég úgy próbálta orvosolni, hogy saját emberét ültette be a tanszékre, hogy a kollégákat „felügyelje”. Olyan történetet is elmeséltek, hogy egy egyetemistákból álló csapat világversenyt nyert informatikában, meg is keresték óket a multik, de terméket soha nem adtak le, ez a fajta tevékenység már nem érdekelte ốket. 


\section{Vélemények az oktatás helyzetéról}

A frissen végzettek tudásával többé-kevésbé meg vannak elégedve a cégek, a gyakorlati ismeretekben tartják leginkább gyengének az egyetemekról kikerülőket, mivel az oktatási rendszer nagyon lassan követi a technológiai fejlődést. Nehéz olyan kész szoftverfejlesztốt találni, aki azonnal képes beszállni a munkába, többen elmondták, hogy legalább hat hónap, amíg betanítják ôket. E probléma áthidalására a cégek egy jó része igyekszik gyakornokként egyetemistákat és PhD-hallgatókat fogadni, így egyben lehetőségük van a legjobbak „lehalászására” is. Nemcsak a szakmai tudást mérlegelik, az is nagyon fontos, hogy csapatember legyen a kiválasztott.

Legnagyobb hiány szoftverfejlesztốkben van, ráadásul a legjobbak külföldre mennek dolgozni. Ezért is értenek egyet azzal a törekvéssel a megkérdezett vállalatok, hogy növelni kell a természettudományos végzettségúek számát és ezzel együtt az informatikusokét. A szakemberhiány, társulva a forráshiánnyal, behatárolja a cégek innovációs lehetóségeit, a jó ötleteket pedig lassabban tudják piacképes termékké fejleszteni. Nem tehetik meg például mindig, hogy a legjobb szakembereket kivonják az ügyfélprojektekból.

\section{A pályázati lehetôségek megítélése}

A négy legkisebb létszámú cég kivételével mindegyik részt vesz magyar vagy uniós pályázatokon, amelyek nem, azok hitelt sem vesznek fel, saját forrásokból fejlesztenek. Van, aki a túl nagy bürokráciával magyarázza az elfordulást e forrásoktól, s hogy így rá lennének kényszerülve, hogy jogászokat alkalmazzanak. Egy másik cég nem talál partnereket, egyedül ellenben reménytelennek tartják a pályázatok elnyerését, s nem tudnak beszállni az EU-pályázatokba sem az üzleti elvárások miatt. 50\%-ot az EU ad, de a másik 50\%-ot árbevételból kell kitermelni. E cégnél a saját forrás sem elegendő a fejlesztések finanszírozására, ezért is álltak le a $\mathrm{K}+\mathrm{F}$ tevékenységgel, illetve úgy látják, nincs igény a felhasználók részéról az innovációkra. Az előírt árbevételi követelményeket is irreálisnak tartják többen, s két cég is felvetette, hogy csak a múszaki részt finanszírozzák a pályázatok, a marketinget és értékesítést ellenben nem. E cégek csak pályázati pénzek segítségével tudják (tudnák) az egész innovációs ciklus finanszírozási igényeit lefedni. Az egyik cégnél például kifejlesztettek egy molekulakutató algoritmust, ami a gyógyszerkutatás területén segít megtalálni az adott problémára a megfelelő tulajdonságokkal rendelkezó molekulákat. 70 milliós projekt volt, melynek a felére kaptak támogatást, de ahhoz, hogy kilépjenek a világpiacra, még jelentôs tốke kellett volna.
A pályázatok hosszú átfutási ideje lassítja az innovációs folyamatokat, márpedig ebben az iparágban az idő különösen fontos tényezô. Sokszor úgy érzik a cégek, hogy a pályázatok elbírálása nem szakszerú, például kevésbé lényeges dolgokat kérnek túlságosan szigorúan számon. A két legnagyobb és legtốkeerósebb vállalat a leginkább elégedett a pályázati rendszerrel, ók könnyebben át tudják hidalni, ha esetleg késnek a kifizetések.

\section{Összegzés}

Kutatásunk nagyrészt alátámasztja a korábbi hasonló felmérések eredményét, melyek szerint a hazai innováció egyik fontos akadályozó tényezóje a finanszírozási források szúkössége. A vállalatok nagy részének nincs pénze $\mathrm{K}+\mathrm{F}-\mathrm{re}$, innovációra, korlátozottak a lehetôségeik külsố források bevonására a banki hitelfeltételek miatt, s sokan a pályázatokon sem indulnak, mert nem tudják a saját erốt biztosítani, de elriasztják óket a megtérülési követelmények is. Pályázatok nélkül mindenesetre a cégek túlnyomó többsége nem tudna technológiát korszerúsíteni, fejlesztési tevékenységet végezni. A konkrét megrendelésre történő fejlesztések finanszírozása általában kevésbé okoz gondot, ellenben a legjobb helyzetben lévő́k is csak pályázati pénzek igénybevételével tudják megvalósítani a hosszabb távú $\mathrm{K}+\mathrm{F}$ projekteket és a jelentősebb technológiafejlesztéseket. A pályázatok körüli anomáliák csökkentése - amelyeket szinte mindenki megemlített - nagyon megkönnyítené a vállalatok életét, s visszahozna olyanokat is a rendszerbe, akiket már „sikerült” elrettenteni.

Elsôsorban a jobb gazdasági helyzetben lévô cégek a finanszírozás helyett inkább a megfelelö kvalitású szakemberek hiányában látják az innováció fó gátját. A jármú- és gépipari vállalatok a jól képzett szakmunkások hiányát is a technológiai adaptáció, és ezen keresztül az innováció egyik fontos akadályának tartják. Többen említették a gyakorlati képzés gyengeségeit vagy éppen hiányát a mérnök- és szakmunkásképzésben. Ez utóbbi egyrészt azzal jár, hogy sokáig tart a frissen végzettek belerázódása a gyakorlatba, másrészt olyan vélemény is elhangzott, hogy sokszor a vállalati életben már olyan új tudományos eredményeket alkalmaznak, technológiákat használnak, amelyekról az egyetemekról kikerülók nem hallottak.

Bár az egyetemek és a vállalatok innovációs együttmúködésében az eltérô szervezeti kultúrák okoznak némi súrlódást, $\mathrm{s}$ nem mindig sikerül sem az egyetemi ügyintézésnek, sem az egyes részt vevő kollégáknak felvenni az üzlet diktálta tempót, a fejlesztési tevékenységet folytató cégek összességében hasznosnak 
tartják az egyetemekkel való együttmúködést. Például bizonyos mérések, kísérletek, tesztek elvégzésére az egyetemeknek van meg a múszerparkja, ilyeneket fenntartaniuk nem lenne célszerú, s vannak olyan $\mathrm{K}+\mathrm{F}$ feladatok, amelyekhez az egyetemeken vannak meg a szellemi kapacitások. A jármúipari cégek közül a $\mathrm{K}+\mathrm{F}$ iránt leginkább elkötelezettek éltek a regionális egyetemi tudásközpontok kínálta anyagi és tudományos lehetôségekkel. A hasonló elkötelezettségú IT-cégek is keresik az egyetemi kapcsolatokat, néhányan nemzetközi $\mathrm{K}+\mathrm{F}$ projekteknek is résztvevôi. Mint többen elmondták, az IT húzóágazattá válásának egyik kulcsa az lenne, ha minél nagyobb számban vennének részt hazai vállalatok nemzetközi együttmúködésekben, uniós projektekben.

\section{Felhasznált irodalom}

Eustat (2006): Hampered innovation activities. http://epp. eurostat.ec/extratction/retrieve/en/theme9/inn/inn cis5_ham (Letöltés ideje: 2009-03-26)

Kiss J. (2005): A magyar vállalatok innovációs tevékenysége. BCE Versenyképesség Kutató Központ, Versenyben a világgal 2004-2006. Múhelytanulmány

Klick (2006): A termékfejlesztés a versenyképesség kulcsa. http://www.klick.hu/cikk_id=15135 (Letöltés ideje: 2008-09-23)

OECD (2008): Reviews of Innovation Policy: Hungary

Cikk beérkezett: 2010. 7. hó

Lektori vélemény alapján véglegesítve: 2010. 9. hó 